\title{
Pengaruh Dana Pihak ketiga, Non Performing Loan, Capital Adequacy Ratio, Tingkat Suku Bunga dan Arus Kas Terhadap Penyaluran Kredit
}

\author{
Igarniwau01@gmail.com \\ Universitas Prima Indonesia
}

\begin{abstract}
ABSTRAK
Penelitian bertujuan menguji pengaruh Dana Pihak Ketiga, Non Performing Loan, Capital Adequacy Ratio, Tingkat Suku Bunga, dan Arus Kas terhadap Penyaluran Kredit pada Perusahaan Perbankan yang terdaftar di Bursa Efek Indonesia periode 2013-2016. Metode pendekatan kuantitatif dengan jenis penelitian adalah deskriptif kuantitatif. Populasi penelitian dan sampel sebanyak 4 tahun atau 48 bulan (data) laporan Dana Pihak Ketiga, Non performing Loan, Capital Adequacy Ratio, Tingkat suku Bunga dan Arus Kas yaitu dari Tahun 2013-2016, dengan teknik pengambilan sampel teknik sampel jenuh, metode analisis yang digunakan dalam penelitian ini adalah metode regresi linier berganda yang di olah dengan menggunakan SPSS. Hasil penelitian ini menunjukkan secara simultan, Dana Pihak Ketiga, Non Performing Loan berpengaruh signifikan terhadap Penyaluran Kredit pada Perusahaan Perbankan. Secara parsial variabel Dana Pihak Ketiga, Non Performing Loan berpengaruh negatif signifikan terhadap Penyaluran Kredit pada Perusahaan Perbankan. Secara parsial variabel Capital Adequacy Ratio, Tingkat Suku Bunga, tidak berpengaruh signifikan terhadap Penyaluran Kredit pada Perusahaan Perbankan. Namun variabel Arus Kas berpengaruh signifikan terhadap Penyaluran Kredit pada Perusahaan Perbankan. Hasil analisis koefisien determinasi di peroleh dari nilai $\mathrm{R} 2$ sebesar $13,8 \%$, artinya variasi nilai perusahaan dapat dijelaskan dari variabel Dana Pihak Ketiga, Non performing Loan, Capital Adequacy Ratio, Tingkat Suku Bunga, dan Arus Kas sebesar 13,8\%, sedangkan sisanya dijelaskan oleh variabel bebas lainnya.
\end{abstract}

Keywords : Dana Pihak Ketiga, Non Performing Loan, Capital Adequacy Ratio,

Tingkat Suku Bunga dan Arus Kas

\section{PENDAHULUAN}

Perkembangan pembangunan ekonomi di suatu negara sangat bergantung pada perkembangan dinamis dan kontribusi nyata dari sektor perbankan. Bank merupakan lembaga keuangan yang fungsinya sebagai perantara keuangan antara pihak yang kelebihan dana (surplus unit) dan pihak yang kekurangan dana (defisit unit). Bank umum (commercial bank) memiliki peranan yang penting menggerakkan Ekonomi Nasional, karena lebih dari 95\% Dana Pihak Ketiga (DPK) perbankan nasional yang meliputi Bank Umum (Commercial Bank), Bank Syariah (Sharia Bank), dan Bank Pengkreditan Rakyat (Rural Bank) berada di Bank Umum.

Penyaluran kredit bank lebih lambat ketimbang simpanan nasabah. Penyaluran kredit bank lebih lambat karena pertumbuhan kredit lebih rendah dibandingkan dengan Dana Pihak Ketiga (DPK). Ini Menunjukkan, kecepatan nasabah menyetor uang ke bank lebih tinggi ketimbang penyaluran kredit oleh bank.(https://m.kontan.co.id).

Beberapa penelitian terdahulu telah dilakukan untuk melihat faktor yang mempengaruhi penyaluran kredit pada perbankan, diantaranya adalah Pujiati (2013) melakukan penelitian pengaruh non performing loan, capital adequacy ratio, dan dana pihak ketiga terhadap penyaluran kredit pada PT Bank Central Asia Tbk, hasil penelitiannya menunjukkan bahwa NPL dan CAR tidak berpengaruh terhadap penyaluran kredit sedangkan DPK berpengaruh terhadap penyaluran 
kredit. Grahadika (2013) melakukan penelitian pengaruh Loan to Deposit Ratio, capital adequacy ratio, non performing loan dan BI rate terhadap kredit UMKM di Bank Umum Provinsi Bali. Hasil penelitiannya menunjukkan bahwa CAR berpengaruh positif dan signifikan terhadap kredit (jangka panjang), NPL dalam jangka panjang berpengaruh negatif dan signifikan terhadap kredit dan BI rate berpengaruh signifikan terhadap kredit.Berbagai hasil penelitian tersebut menunjukkan adanya pengaruh DPK, NPL, dan CAR terhadap penyaluran kredit menunjukkan hasil yang berbeda-beda,untuk itu perlu dilakukan penelitian kembali. Maka peneliti tertarik untuk membahas mengenai: "Pengaruh Dana pihak ketiga, Non Performing Loan, Capital Adequacy Ratio, Tingkat Suku Bunga, Dan Arus Kas Terhadap Penyaluran Kredit Pada Perusahaan Perbankan Yang Terdaftar di BEI Periode 20132016."

\subsection{Dana Pihak Ketiga}

Menurut Budisantoso (2014:124), dana pihak ketiga,yaitu sumber dana yang berasal dari dana sendiri,dana dari deposan,dana pinjaman,dan sumber dana lain.

Rumus untuk mencari DPK menurut Pujiati dkk (2013:467) adalah:

DPK $=$ Giro+Tabungan + Deposito

\subsection{Non Performing Loan}

Menurut Ismail (Ismail, 2011), Kredit Non Performing Loan merupakan kredit yang sudah dikategorikan kredit bermasalah, karena sudah terdapat tunggakan. sedangkan kredit bermasalah adalah kredit-kredit yang kategori kolektibilitasnya masuk dalam kriteria kurang lancar, kredit diragukan dan kredit macet (Dendawijaya, 2009). berikut :

Pujiati merumuskan perhitungan NPL sebagai

$$
N P L=\frac{\text { Kredit kualitas macet }}{\text { Total kredit }} X 100 \%
$$

Non Performing Loan disebabkan oleh kredit kualitas kurang lancar dan diragukan dan macet.

\subsection{Capital Adequacy Ratio}

Capital Adequacy Ratio merupakan rasio untuk mengukur permodalan dan cadangan penghapusan dalam menanggung pengkreditan, terutama resiko yang terjadi karena bunga gagal ditagih (Kasmir, 2012).

Aktiva tertimbang menurut resiko adalah nilai total aktiva bank setelah dikalikan dengan masingmasing bobot resiko tersebut. Aktiva yang paling tidak beresiko diberi bobot $0 \%$ dan aktiva yang beresiko diberi bobot $100 \%$. Dengan demikian, aktiva tertimbang menurut resiko menunjukkan nilai aktiva beresiko yang memerlukan antisipasi modal dalam jumlah yang cukup (Wardiah, et al., 2013)

Dalam menghitung Capital Adequacy Ratio menurut resiko akitva tertimbang adalah

$\mathrm{CAR}=\frac{\text { Modal }}{\mathrm{ATMR}} \times 100 \%$

\subsection{Tingkat Suku Bunga}

Menurut Kasmir (Kasmir, 2013) Bunga dapat diartikan sebagai balas jasa yang diberikan oleh bank berdasarkan prinsip konvensional kepada nasabah yang membeli atau menjual produknya. Atau harga yang harus dibayar kepada nasabah yang memiliki simpanan) dengan yang harus oleh nasabah kepada bank (nasabah yang memperoleh pinjaman

Menurut Pandia (2011:12), tingkat bunga merupakan imbalan atau kontraprestasi yang diberikan oleh bank kepada penyimpanan dana.Suku bunga yang tinggiakan mendorong masyarakat untuk menghemat pengeluaran konsumsinya dan menyimpan bagian yang lebih dari aktiva totalnya dalam bentuk memberikan penghasilan.

Indikator yang digunakan dalam penelitian ini berasal dari data BI Rate. Data BI Rate sebgai suku bunga acuan merupakan kebijakan yang mencerminkan sikap atau stance kebijakan moneter yang ditetapkan oleh Bank Indonesia dan diumumkan kepada publik. Data BI Rate bisa diakses melalui www.bi.go.id

\subsection{Penyaluran Kredit}

Menurut Kasmir (2014:162), dalam bahasa sehari-hari kata kredit sering diartikan memperoleh barang dengan membayar cicilan atau dengan angsuran dikemudian hari atau memperoleh pinjaman uang yang pembayarannya dilakukan dengan perjanjian. Jadi, dapat diartikan bahwa kredit dapat berbentuk uang atau barang. Baik dalam bentuk uang ataupun barang metode pembayarannya dengan metode angsuran atau cicilan.

Menurut Abdullah dan Tantri (2014:162163), istilah kredit berasal dari bahasa Yunani credere yang berarti kepercayaan (truth atau faith). 
Oleh karena itu, dasar dari kredit adalah kepercayaan. Seseorang atau suatu badan yang memberikan kredit percaya bahwa penerima kredit (debitur) pada masa yang akan datang akan sanggup memenuhi segala sesuatu yang telah dijanjikan. Apa yang telah dijanjikan dapat beupa barang, uang, ataupun jasa. Maka arti kredit dalam ilmu ekonomi adalah penundaan pembayaran dari prestasi yang diberikam sekarang, baik dalam bentuk barang, uang, maupun jasa.

1.6. Pengaruh Dana Pihak Ketiga Terhadap

Penyaluran Kredit

Menurut Triandara dan Budisantosio (2008:112), untuk mengukur jumlah dana pihak ketiga yang disalurkan dalam bentuk kredit. Resiko kredit terhadap total dana pihak ketiga yang tinggi menunjukkan bahwa bank yang bersangkutan berada dalam keadaan kurang likuid yang berarti berarti kemampuan bank untuk memenuhi kewajiban jangka pendek.

Menurut Kasmir (2014:3), bank adalah lembaga keuangan yang kegiatan usahanya adalah menghimpun dana dari masyarakat (DPK) dan menyalurkan kembali dana tersebut dalam bentuk kredit.

1.7. Pengaruh Non Performing Loan Terhadap Penyaluran Kredit

Menurut Hariyani (2010:52), rasio NPL atau rasio kredit bermasalah ini menunjukkan bahwa kemampuan manajemen bank dalam rangka mengelola kredit bermasalah yang diberikan oleh bank. Sehingga semakin tinggi rasio ini maka akan semakin buruk kualitas kredit bank yang menyebabkan jumlah kredit bermasalah semakin besar maka kemungkinan suatu bank dalam kondisi bermasalah semakin besar.

Menurut Taswan (2010:451), kredit akan berkualitas atau tidak berkualitas dimulai saat analisis kredit. Kesalahan analisis kredit akan menyesatkan pemberian kredit. Keputusan kredit yang salah merupakan potensi terjadinya kredit bermasalah.

1.8. Pengaruh Capital Adequacy Ratio Terhadap Penyaluran Kredit

Menurut Wardiah (2013:348)

berdasarkan rasio Capital Adequacy Ratio, apabila bank akan menambah penyaluran kredit kepada masyarakat, dengan sendirinya bank harus menambah modal yang dimiliki. Apabila tidak menambah jumlah kredit, Capital Adequancy Ratio yang dicapai bank lebih kecil.

Menurut Greuning dan Bratanovic (2011:105), hampir setiap aspek perbankan baik secara langsung maupun tidak langsung dipengaruhi oleh ketersediaan dan biaya modal. Modal adalah salah satu faktor kunci yang harus dipertimbangkan dalam menilai keamanan dan kesehatansebuah bank. Modal dasar yang memadai berfungsi sebagai jaring pengaman untuk berbagai resiko yang dihadapi sebuah institusi dalam menjalankan sebuah usahanya. Modal menyerap potensi kerugian dan dengan demikian menyediakan dasar untuk menjaga kepercayaan nasabah pada bank. Modal juga merupakan faktor penentu utama kapasitas pinjaman sebuah bank.

\subsection{Pengaruh Tingkat Suku Bunga Terhadap Penyaluran Kredit}

Menurut Triandara dan Budisantosio (2008:106), apabila bank menetapkan tingkat bunga pinjaman yang terlalu tinggi, maka calon debitur tidak akan mau meminjam dana dari bank dan debitur lama akan mengalami kesulitan membayar bunga karena tidak mamp

Menurut Kasmir (2014:114), dalam kegiatan sehari-hari ada dua macam bunga yang diberikan kepada nasabahnya yaitu: Bunga simpanan dan bunga pinjaman. Kedua macam bunga ini merupakan komponen utama faktor biaya dan pendapatan bagi bank. Bunga simpanan merupakan biaya dana yang yang harus dikeluarkan kepada nasabah, sedangkan bunga pinjaman merupakan bunga pendapatan yang diterima dari nasabah. Bunga simpanan maupun bunga pinjaman masing-masing saling memengaruhi satu sama lainnya. Total biaya dana tergantung dari seberapa besar bunga yang ditetapkan untuk memperoleh dana yang diinginkan. Semakin besar bunga yang dibebankan terhadap bunga simpanan, semakin tinggi pula biaya dananya demikian pula sebaliknya.

1.10. Pengaruh Arus Kas Terhadap Penyaluran Kredit

Menurut Fahmi (2014:32), penguatan kas dipengaruhi oleh faktor-faktor dan item-item yang ada di current asset dan non current liabilities/fixed asset. Karena bagi perusahaan dalam menjalankan aktivitas bisnisnya ia menganut prinsip "going concern" atau keberlangsungan usaha/bisnis. Jadi perusahaan tidak mengenal titik awal dan titik akhir.

\section{KERANGKA KONSEPTUAL}

Dana pihak ketiga, Non Performing Loan, Captal Adequacy Ratio, Tingkat Suku Bunga dan Arus Kas mempengaruhi kredit perbankan. Dengan begitu pihak manajemen perusahaan harus menjaga keseimbangan sumber dana dan resiko 
kredit perusahaan. Semakin besar dana pihak, modal yang cukup, tingkat suku bunga dan arus kas maka semakin meningkat pula penyaluran kredit oleh bank. Namun semakin besar kredit yang bermasalah, maka semakin menurun penyaluran kredit. Secara parsial dana pihak ketiga, non performing loan, capital adequacy ratio, non performing loan, tingkat suku bunga dan arus kas berpengaruh terhadap kredit yang disalurkan dan secara simultan dana pihak ketiga, non performing loan, capital adequacy ratio, tingkat suku bunga dan arus kas berpengaruh terhadap kredit yang disalurkan.

Dari penjelasan diatas maka kerangka konseptual sebagai berikut:

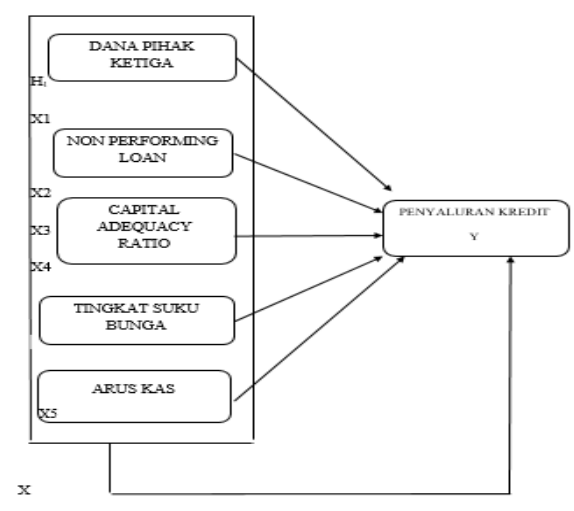

\section{GAMBAR}

KERANGKA KONSEPTUAL

HIPOTESIS PENELITIAN

Berdasarkan rumusan masalah, tujuan, teori, penelitian terdahulu hubungan antar variabel, dan kerangka pemikiran, maka adalah:

hipotesis yang diajukan dalam penelitian ini

H1 : Terdapat pengaruh Dana Pihak Ketiga terhadap penyaluran kredit pada perusahaan perbankan yang terdaftar di Bursa Efek Indonesia periode 2013-2016.

H2 : Terdapat pengaruh Non performing Loan terhadap penyaluran kreditpada perusahaan perbankan yang terdaftar di Bursa Efek Indonesia periode 2013-2016.

H3 : Terdapat pengaruh Capital Adequacy Ratio terhadap penyaluran kredit pada perusahaan perbankan yang terdaftar di Bursa Efek Indonesia Periode 2013-2016

H4 : Terdapat pengartuh Tingkat Suku Bunga terhadap penyaluran kredit pada perusahaan perbankan yang terdaftar di Bursa Efek Indonesia Periode 2013-2016.

H5 : Terdapat pengaruh Arus Kas terhadap penyaluran kredit pada perusahaan perbankan yang terdaftar di Bursa Efek Indonesia Periode 2013-2016.

H6 : Terdapat pengaruh Dana Pihak Ketiga, Non performing loan,Capital Adequacy Ratio, Tingkat Suku Bunga, Arus Kas Terhadap Penyaluran Kredit Pada Perusahaan yang Terdaftar di Bursa Efek Indonesia Periode 2013-2016.

\section{Metodologi Penelitian}

3.1. Pendekatan Penelitian

Dalam Pendekatan kuantitatif hakikat di antara hubungan variabel-variabel di analisis dengan menggunakan teori yang objektif (Sujarweni \& Wiratna, 2015).

Populasi sasaran yaitu populasi yang digunakan untuk menjadi sasaran penelitian. Sesuai dengan penelitian yang akan diteliti yaitu Pengaruh Dana Pihak Ketiga, Non Performing Loan,Capital Adequacy Ratio, Tingkat Suku Bunga Dan Arus Kas Terhadap Penyaluran Kredit maka yang menjadi populasi dalam penelitian adalah semua perusahaan perbankan yang terdaftar di Bursa Efek Indonesia mulai dari tahun 2013 hingga tahun 2016 dan telah memberi laporan keuangan perusahaan, sehingga diperoleh jumlah populasi sebanyak 43 perusahaan.

Penelitian ini menggunakan teknik purposive sampling. purposive sampling adalah teknik mengambil sampel dari populasi yang diperkirakan paling cocok utnuk dikumpulkan datanya dan pengambilan data disesuaikan dengan kriteria-kriteria yang telah ditentukan (Sujarweni \& Wiratna, 2015)

Sampel dalam penelitian ini menjadi 31 sampel $\mathrm{x} 4$ Tahun $=124$ tahun

Adapun Jenis penelitian yang digunakan peneliti adalah penelitian deskriptif kuantitatif Sumber data yang digunakan peneliti adalah data sekunder. Data sekunder adalahdata yang sudah tersedia dan dikumpulkan oleh pihak lain.Data sekunder yang diperoleh peneliti dari internet dengan website www.idx.co.id untuk perusahaan perbankan yang terdaftar di Bursa Efek Indonesia yang mempublikasikan laporan keuangannya (Sanusi, 2012) 


\subsection{Model Analisis Data}

Seluruh data penelitian yang telah dikumpulkan untuk diolah, kemudian akan dianalisis untuk memperoleh jawaban atasa permasalahan yang timbul dalam penelitian ini. Dalam menganalisis data, penelitian menggunakan program SPSS.

Dalam penelitian ini digunakan metode analisis statistik deskriptif yang memberikan gambaran atau deskripsi suatu data yang dilihat dari nilai rata-rata (mean) standar deviasi, varian, maksimum, minimum, sum, range, kurtosis, skewness (kemencengan distribusi) Ghozali (2013:19).

\subsection{Analisis Linear Berganda}

Model analisis data yang digunakan dalam penelitian ini adalah analisis regresi linear berganda (multiple linier regression). Analisis ini digunakan untuk mengukur pengaruh Dana Pihak Ketiga, Non Performing Loan, Capital

Adequacy Ratio, Tingkat Suku Bunga Dan Arus Kas Terhadap Penyaluran Kredit. Adapun rumus dari regresi linear berganda adalah sebagai berikut:

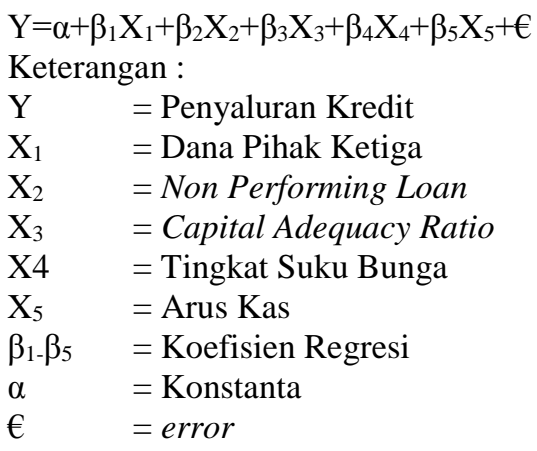

\section{Hasil Penelitian}

\section{Hasil Uji Asumsi Klasik}

Hasil Uji Normalitas

Uji normalitas yang digunakan untuk menguji apakah data yang berdistribusi normal atau tidak yaitu dengan menggunakan analisis grafik dan analisis statistic.

\section{Tabel IV.1}

\section{Hasil Statistik Deskriptif}

\begin{tabular}{l} 
Descriptive Statistics \\
\hline
\end{tabular}

Dalam penelitian sampel yang awalnya 124 menjadi 100 dikarenakan data tidak berdistribusi normal maka penelitian ini menggunakan data transform (ln) untuk memperbaiki data tersebut.

\section{Analisis Grafik Histogram Setelah Transformasi Data}

\section{Gambar IV.2}

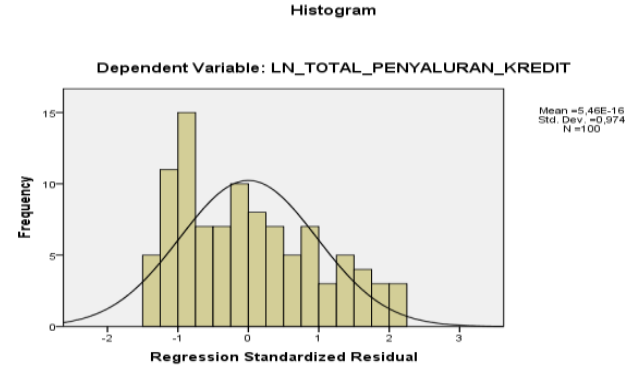

Sumber:Pengolahan Data SPSS 2018

Dari histogram tersebut, dapat disimpulkan data residual berdistribusi normal karena dapat dilihat dari arah histogram yang tidak miring ke kanan maupun ke kiri dan membentuk lonceng terbalik.

Analisis Grafik Normal ProbabilityPlot Sesudah Transformasi Data

Tabel IV.3

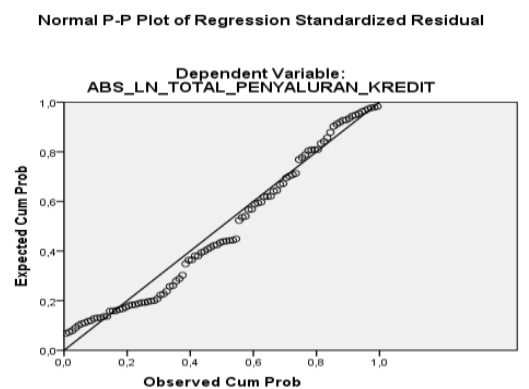

Sumber : Pengolah Data SPSS 2018

Hasil uji Grafik di atas menunjukkan distribusi residual yang normal. Hal ini di tunjukkan grafik normal probabilityplot yang menunjukkan dimana terlihat titik-titik menyebar disekitar garis diagonal sehingga berdistribusi secara normal. 
Tabel IV.4

Hasil Uji Multikolinieritas Setelah Transformasi Data coefficients

\begin{tabular}{|c|c|c|c|c|c|c|c|}
\hline \multirow[b]{2}{*}{ Model } & \multicolumn{2}{|c|}{$\begin{array}{l}\text { Unstandard } \\
\text { Coefficients }\end{array}$} & $\begin{array}{l}\text { Stand } \\
\text { ard } \\
\text { Coef. }\end{array}$ & \multirow[b]{2}{*}{$\mathrm{T}$} & \multirow[b]{2}{*}{ Sig. } & \multicolumn{2}{|c|}{$\begin{array}{l}\text { Collinearity } \\
\text { Statistics }\end{array}$} \\
\hline & B & $\begin{array}{l}\text { Std. } \\
\text { Error }\end{array}$ & Beta & & & Tolrnce & VIF \\
\hline 1 (Constant) & 7,089 & 4,220 & & 1,680 & 096 & & \\
\hline ABS Ln dpk & 010 & 174 & 008 & 059 & 953 & 465 & 2,153 \\
\hline ABS Ln npl & 619 & 181 & 394 & 3,425 & 001 & 658 & 1,519 \\
\hline ABS Ln car & 109 & 126 & 095 & 861 & 391 & 716 & 1,397 \\
\hline ABS Ln tsb & 308 & 1,859 & 016 & 166 & 869 & 900 & 1,111 \\
\hline \begin{tabular}{|l|} 
ABSLn \\
aruskas
\end{tabular} & 124 & 154 & 098 & 802 & 425 & 577 & 1,732 \\
\hline
\end{tabular}

a. Dependent Variable: ABS_Ln-Total penyaluran kredit Sumber Pengolah Data SPSS 2018

Tabel IV.5

One-Sample Kolmogorov-Smirnov Test Setelah Transformasi

One-Sample Kolmogorov-Smirnov Test

\begin{tabular}{|c|c|}
\hline & Unstandardized Residual \\
\hline $\mathrm{N}$ & 100 \\
\hline \begin{tabular}{l|l} 
Norm & Mean \\
\cline { 2 - 2 }
\end{tabular} &, 0000000 \\
\hline \begin{tabular}{l|l} 
al & Std. \\
Param & Deviati \\
eters ${ }^{\mathrm{a},}$, & on \\
$\mathrm{b}$ &
\end{tabular} & 4,14362910 \\
\hline \begin{tabular}{l|l} 
Most & Absolut \\
Extre & e
\end{tabular} &, 102 \\
\hline me Positive &, 102 \\
\hline $\begin{array}{ll}\text { Differ } & \text { Negativ } \\
\text { ences } & \text { e } \\
\end{array}$ &,- 063 \\
\hline $\begin{array}{l}\text { Kolmogorov- } \\
\text { Smirnov Z }\end{array}$ & 1,022 \\
\hline $\begin{array}{l}\text { Asymp. Sig. (2- } \\
\text { tailed) }\end{array}$ &, 248 \\
\hline
\end{tabular}

Sumber : Pengolah Data SPSS 2018

Dari tabel uji normalitas dengan menggunakan Kolmogorov - Smirnov di atas, dapat diketahui bahwa Dana Pihak Ketiga $\left(\mathrm{X}_{1}\right)$, Non Performing Loan $\left(\mathrm{X}_{2}\right)$, Capital Adequacy Ratio $\left(\mathrm{X}_{3}\right)$, Tingkat Suku Bunga $\left(\mathrm{X}_{4}\right)$, Arus Kas $\left(\mathrm{X}_{4}\right)$ dan Penyaluran Kredit (Y) memiliki 0,248> sudah memenuhi syarat distribusi normal. Dengan demikian dapat disimpulkan data pada penelitian ini berdistribusi normal dan dapat digunakan untuk melakukan uji lainnya karena memiliki nilai signifikan $>0,05$.

\section{Uji Multikolinieritas}

Uji Multikolinieritas bertujuan untuk menguji apakah dalam model regresi ditemukan adanya korelasi antar variabel bebas (independen). Untuk mendeteksi ada tidaknya multikolinieritas di dalam model regresi dapat dilihat dari nilai tolerance dan Variance Inflation Factor (VIF). Cara pengambilan keputusan yaitu VIF $\leq 10$ dan nilai tolerance $\geq 0,10$, maka regresi bebas dari multikolinieritas.

\section{Hasil Uji Autokorelasi}

Uji ini bertujuan untuk menguji apakah dalam model regresi linier ada korelasi antar kesalahan pengganggu pada periode $\mathrm{t}$ dengan kesalahan pengganggu pada periode t-1 (sebelumnya).

Tabel IV.6: Uji Autokorelasi Setelah Transformasi

Model Summary ${ }^{b}$

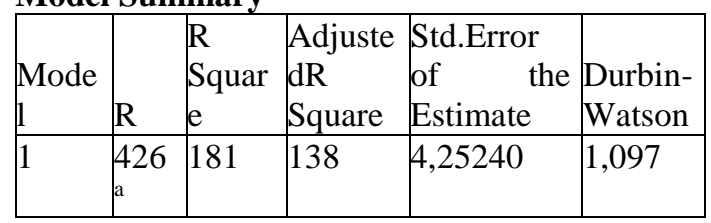

a.Predictors:

(Constant)LN_Aruskas,tsbk,car,npl,dpk

b. Dependent Variable: LN_Total penyaluran kredit

Sumber Pengolahan Data 2018

Gambar IV.7

Uji Scatterplot Setelah Transformasi

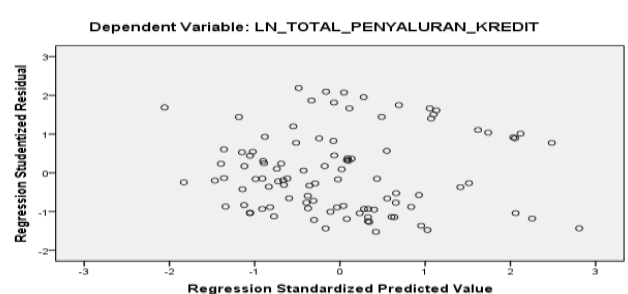

Sumber: Hasil Pengolahan Data SPSS 2018

Grafik Scatterplot pada gambar IV.8 di atas dapat dilihat bahwa titik-titiknya menyebar secara acak serta menyebar membentuk pola yang baik di atas maupun di bawah angka 0 pada sumbu Y,. Hal ini dapat disimpulkan bahwa tidak terjadi heteroskedastisitas pada model regresi. 
Tabel IV.8

\section{Uji Glejser Setelah Transformasi}

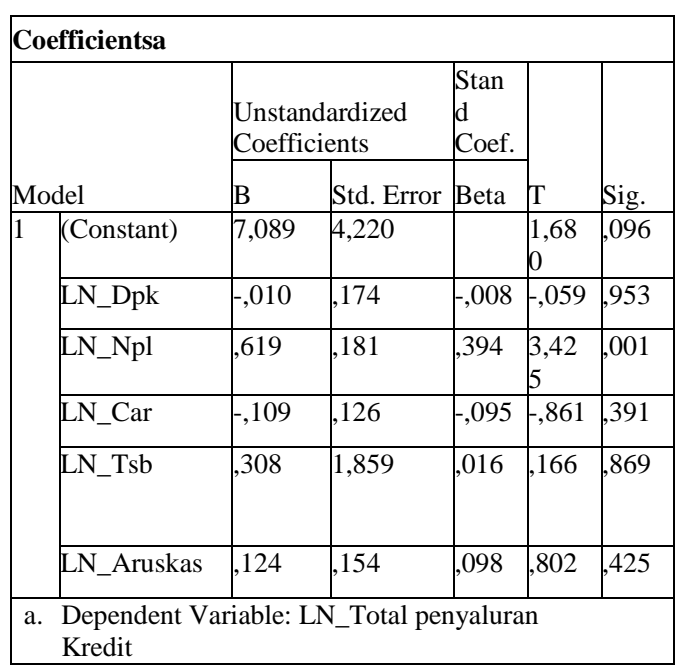

\section{Sumber Pengolahan Data 2018}

Hasil penelitian pada Tabel IV.8 dapat dilihat bahwa tingkat signifikan untuk Dana Pihak Ketiga $\left(\mathrm{X}_{1}\right)$ adalah $0.953>0,05$ maka dapat disimpulkan tidak terjadi heteroskedastisitas, Non Performing Loan $\left(\mathrm{X}_{2}\right)$ adalah $0,001>0,05$ maka dapat disimpulkan terjadi heteroskedastisitas, Capital Adequacy Ratio $\left(\mathrm{X}_{3}\right)$ adalah 0,391 >0.05 maka dapat disimpulkan tidak terjadi heteroskedastisitas, Tingkat Suku Bunga $\left(\mathrm{X}_{4}\right)$ adalah $0.869<0.05$ maka dapat disimpulkan tidak terjadi heteroskedastisitas, dan Arus Kas $\left(X_{4}\right)$ adalah 0,425 > 0,05 maka dapat disimpulkan tidak terjadi heteroskedastisitas pada penelitian ini.

\section{Hasil Analisis Data Penelitian}

\section{Analisis Regresi Linier Berganda}

Metode analisis yang digunakan adalah analisis regresi linier berganda. Analisis analisis regresi linier berganda untuk mencari hubungan atau pengaruh antara variabel dependen dengan independen. Berikut adalah tabel koefisien linier berganda :
Tabel IV.9 : Hasil Uji Regresi Linier Berganda

\begin{tabular}{|c|c|c|c|c|c|}
\hline \multicolumn{6}{|l|}{ Coefficients $^{\mathrm{a}}$} \\
\hline \multirow[b]{4}{*}{ Model } & \multicolumn{3}{|c|}{ Unstandardized Standardized } & \multirow[b]{4}{*}{$\mathrm{T}$} & \multirow[b]{4}{*}{ Sig. } \\
\hline & Coeff & icients & Coefficients & & \\
\hline & & Std. & & & \\
\hline & $\mathrm{B}$ & Error & Beta & & \\
\hline 1 (Constant) & 7,089 & 4,220 & & 1,680 &, 096 \\
\hline ABS_LN_Dpk &,- 010 &, 174 &,- 008 &,- 059 &, 953 \\
\hline ABS_LN_Npl & ,619 & 181 & 394 & 3,425 &, 001 \\
\hline ABS LN Car &,- 109 & 126 &,- 095 &,- 861 &, 391 \\
\hline ABS_LN_TSb & 308 & 1,859 & 016 & 166 &, 869 \\
\hline ABS_LN_Aruskas &, 124 & 154 & ,098 &, 802 & 425 \\
\hline
\end{tabular}

a. Dependent Variable: ABS_LN_Total penyaluran kredit

\section{Sumber : Pengolahan Data 2018}

Berdasarkan Tabel IV.9 maka diperoleh persamaan regresi linear berganda hipotesis penelitian yaitu sebagai berikut :

LnTotal Penyaluran Kredit $=-7,089-0,10$ Ln Dana Pihak Ketiga + 0,619 Npl-1,09 Car +0,308 Tingkat Suku Bunga $+0,124$ Arus Kas.

Koefisien-koefisien persamaan linier berganda di atas dapat diartikan sebagai berikut :

1. Nilai konstanta (a) adalah $-7,089$ artinya jika variabel bebas yaitu Dana Pihak Ketiga, Non Performing Loan, Capital Adequacy Ratio, Tingkat Suku Bunga, dan Arus Kas dianggap konstan, maka total penyaluran kredit pada perusahaan perbankan yang terdaftar di Bursa Efek Indonesia sebesar -7,089.

2. Koefisien regresi Dana Pihak Ketiga (X1) adalah 0,10 ini menujukkan bahwa setiap penurunan dana pihak ketiga satu kali maka akan diikuti kenaikan nilai perusahaan sebesar 0,10 .

3. Non Performing Loan (X2) adalah 0,619 ini menujukkan bahwa setiap kenaikan Non Performing Loan satu kali maka akan diikuti kenaikan niklai perusahaan sebesar 0,619.

4. Capital Adequacy Ratio (X3) adalah 0,109 ini menujukkan bahwa setiap kenaikan Capital Adequacy Ratio satu kali maka akan diikuti kenaikan nilai perusahaan sebesar 0,109

5. Tingkat Suku Bunga (X4) adalah 0,308 ini menujukkan bahwa setiap kenaikan Tingkat Suku Bunga satu kali maka akan diikuti kenaikan nilai perusahaan sebesar 0,308

6. Arus Kas (X4) adalah 0,124 ini menujukkan bahwa setiap kenaikan Arus Kas satu kali maka akan diikuti kenaikan nilai perusahaan sebesar 0,124

Koefisien Determinasi $\left(\mathbf{R}^{2}\right)$ 
Nilai koefisien determinasi digunakan untuk mengukur seberapa kuat variabel independen mempengaruhi variabel dependennya. Nilai Adjusted $\mathrm{R}^{2}$ dapat bernilai negatif, walaupun yang dikehendaki harus bernilai positif. Dalam uji empiris didapat bila nilai Adjusted $\mathrm{R}^{2}$ negatif, maka nilai Adjusted $\mathrm{R}^{2}=0$. Secara sistematis jika $\mathrm{R}^{2}=0$, maka Adjusted $\mathrm{R}^{2}=(1-\mathrm{k}) /(\mathrm{n}-\mathrm{k})$. Jika $\mathrm{k}<1$, maka Adjusted $\mathrm{R}^{2}$ akan bernilai negatif.

Tabel IV. 10: Koefisien Determinasi Model Summary ${ }^{\mathrm{b}}$

\begin{tabular}{|c|c|c|c|c|c|}
\hline & & $\mathrm{R}$ & Adjuste & Std.Error & \\
\hline Mode & & Squ & & of the & Durbin- \\
\hline 1 & $\mathrm{R}$ & are & Square & Estimate & Watson \\
\hline 1 & 426 &, 181 &, 138 & 4,25240 & 1,097 \\
\hline
\end{tabular}

a.Predictors:(Constant),LN_Aruskas,Tsb,Car ,Npl,Dpk

b. Dependent Variable: LN_Total penyaluran kredit

Sumber : Hasil Pengolahan Data 2018

Berdasarkan Tabel IV.10 dapat dilihat hasil output model summaryi bahwa besarnya Adjusted $R$ Square pada tabel sebesar 0,138 . Hal ini berarti $13,8 \%$ variasi nilai perusahaan dapat dijelaskan oleh ke lima variabel independennya yaitu Arus Kas, Tingkat Suku Bunga, NPL, CAR dan DPK. Sedangkan sisanya yaitu dijelaskan oleh sebabsebab yang lain diluar model penelitian seperti Arus Kas, Tingkat Suku Bunga, NPL, CAR dan DPK.

Pengujian Hipotesis Secara Simultan (Uji-F) Uji hipotesis secara simultan (Uji-F) digunakan untuk mengetahui seberapa jauh pengaruh variabel independen terhadap variabel dependen secara simultan atau keseluruhan.

Tabel 12 : Hasil Uji Hipotesis Secara Simultan (Uji-F)

ANOVA $^{b}$

\begin{tabular}{|c|c|c|c|c|c|}
\hline Model & $\begin{array}{l}\text { Sumof } \\
\text { Squares }\end{array}$ & Df & $\begin{array}{l}\text { Mean } \\
\text { Square }\end{array}$ & $\mathrm{F}$ & Sig. \\
\hline 1 Regression & 376,484 & 5 & 75,297 & 4,164 &, $002^{\mathrm{a}}$ \\
\hline Residual & 1699,797 & 94 & 18,083 & & \\
\hline Total & 2076,280 & 99 & & & \\
\hline
\end{tabular}

a. Predictors: (Constant), LN_Arus kas,tTsb,Car,Npl,Dpk

b. Dependent Variable: LN_Total penyaluran kredit

Sumber : Hasil Pengelolahan Data 2018

Dari Tabel IV.12 di atas, bisa dilihat hasil $F_{\text {hitung }}$ sebesar 4,164 sedangkan $F_{\text {tabel }}$ sebesar 2,45 maka kesimpulannya adalah $F_{\text {hitung }}>F_{\text {tabel }}(4.164>$ 2,45 dengan nilai signifikan 0,002 <0,05 maka $\mathrm{H}_{0}$ ditolak dan $\mathrm{H}_{\mathrm{a}}$ diterima yang berarti variabel Arus Kas, Tingkat Suku Bunga, NPL, CAR dan DPK secara Simultan berpengaruh signifikan terhadap Total Penyaluran Kredit pada Perusahaan Perbankan yang terdaftar di Bursa Efek Indonesia Periode 2013-2016.

Pengujian Hipotesis Secara Parsial (Uji-t)

Uji hipotesis secara parsial (Uji-t) digunakan untuk mengetahui seberapa jauh pengaruh variabel independen terhadap variabel dependen parsial atau individu.

Tabel 11 : Hasil Uji Hipotesis Secara Parsial (Uji-t)

Coefficients $^{\mathbf{a}}$

\begin{tabular}{|c|c|c|c|c|c|}
\hline \multirow[b]{2}{*}{ Model } & \multicolumn{2}{|c|}{$\begin{array}{l}\text { Unstand. } \\
\text { Coeff. }\end{array}$} & \begin{tabular}{|l} 
Standd \\
Coef.
\end{tabular} & \multirow[b]{2}{*}{$\mathbf{t}$} & \multirow[b]{2}{*}{ Sig. } \\
\hline & B & $\begin{array}{l}\text { Std. } \\
\text { Error }\end{array}$ & Beta & & \\
\hline \begin{tabular}{|l|l|}
1 & (Constant) \\
\end{tabular} & 7,089 & 4,220 & & 1,680 &, 096 \\
\hline LN_DPK &,- 010 &, 174 &,- 008 &,- 059 &, 953 \\
\hline LN_NPL &, 619 &, 181 &, 394 & 3,425 &, 001 \\
\hline LN_CAR &,- 109 &, 126 &,- 095 &,- 861 &, 391 \\
\hline LN_TSB &, 308 & 1,859 &, 016 &, 166 &, 869 \\
\hline LN_ARUS_KAS &, 124 &, 154 &, 098 &, 802 &, 425 \\
\hline
\end{tabular}

Sumber : Hasil Pengelolahan Data 2018

Dari tabel IV.11 di atas, menunjukkan hasil pengujian statistik secara parsial dimana nilai $t_{\text {tabel }}$ sebesar 1.98552 maka dapat disimpulkan sebagai berikut:

1. Pengujian hipotesis secara parsial (uji t) untuk dana pihak ketiga terhadap penyaluran kredit nilai ${ }^{t}$ hitung adalah $-0,59$ sedangkan tabel sebesar 1.98552, maka - ${ }^{t}$ hitung $\leq{ }^{\mathrm{t}}$ tabel $(-0,59$ $\leq 1.98552$ dan nilai signifikan 0,953 lebih besar dari 0,05 yang berarti $\mathrm{H}_{0}$ diterima dan $\mathrm{H}_{\mathrm{a}}$ ditolak. Artinya dana pihak ketiga tidak berpengaruh terhadap penyaluran kredit pada perusahaan perbankan yang terdaftar di BEI periode 2013-2016.

2. Pengujian hipotesis secara parsial (uji t) untuk Non Performing Loan terhadap penyaluran kredit nilai thitung adalah 3,425 sedangkan tabel sebesar 1.98552, maka - ${ }^{t}$ hitung $\leq{ }^{t}$ tabel $(3,425<1.98552)$ atau ${ }^{t}$ hitung $>$ tabel $(3,425>$ 1.98552 dan nilai signifikan 0,001 lebih kecil dari 0,05 yang berarti $\mathrm{H}_{\mathrm{a}}$ diterima dan $\mathrm{H}_{0}$ ditolak. Artinya Non Performing Loan berpengaruh signifikan terhadap penyaluran kredit pada perusahaan perbankan yang terdaftar di BEI periode 2013-2016.

3. Pengujian hipotesis secara parsial (uji t) untuk Capital Adequacy Ratio terhadap penyaluran kredit nilai ${ }^{t}$ hitung adalah -0,95 sedangkan tabel sebesar 1.98552, maka - ${ }^{t}$ hitung $\leq{ }^{\mathrm{t}}$ tabel (- 
$0,95<1.98552)$ atau ${ }^{t}$ hitung > tabel $(-0,95>$ 1.98552 dan nilai signifikan 0,391 lebih besar dari 0,05 yang berarti $\mathrm{H}_{0}$ diterima dan $\mathrm{H}_{a}$ ditolak. Artinya Capital Adequacy Ratio tidak berpengaruh terhadap penyaluran kredit pada perusahaan perbankan yang terdaftar di BEI periode 2013-2016.

4. Pengujian hipotesis secara parsial (uji t) untuk Tingkat Suku Bunga terhadap penyaluran kredit nilai ${ }^{t}$ hitung adalah 0,166 sedangkan tabel sebesar 1.98552, maka $-{ }^{t}$ hitung $\leq{ }^{t}$ tabel $(0,166<1.98552)$ atau ${ }^{t}$ hitung $>{ }^{t}$ tabel $(0,166>$ 1.98552 dan nilai signifikan 0,869 lebih besar dari 0,05 yang berarti $\mathrm{H}_{\mathrm{a}}$ diterima dan $\mathrm{H}_{0}$ ditolak. Artinya Tingkat Suku Bunga tidak berpengaruh terhadap penyaluran kredit pada perusahaan perbankan yang terdaftar di BEI periode 2013-2016.

5. Pengujian hipotesis secara parsial (uji t) untuk Arus Kas terhadap penyaluran kredit nilai

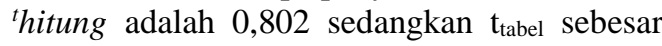
1.98552 , maka $-\mathrm{t}_{\text {hitung }} \leq \mathrm{t}_{\text {tabel }}(0,802<1.98552)$ atau $t_{\text {hitung }}>t_{\text {tabel }}(0,802>1.98552$ dan nilai signifikan 0,425 lebih besar dari 0,05 yang berarti $\mathrm{H}_{\mathrm{a}}$ diterima dan $\mathrm{H}_{0}$ ditolak. Artinya Arus Kas tidak berpengaruh terhadap penyaluran kredit pada perusahaan perbankan yang terdaftar di BEI periode 2013-2016.

\section{PEMBAHASAN HASIL}

\section{Pengaruh Dana Pihak Ketiga Terhadap Penyaluran Kredit}

Berdasarkan hasil uji hipotesis secara parsial (uji t) diperoleh hasil bahwa dana pihak ketiga berpengaruh negatif terhadap penyaluran kredit pada perusahaan perbankan yang terdaftar di BEI periode 2013-2016 dengan nilai $(-0,59 \leq 1.98552$ dan nilai signifikan 0,953 lebih besar dari 0,05 .

Menurut Triandara dan Budisantosio (2008:112) untuk mengukur jumlah dana pihak ketiga yang disalurkan dalam bentuk kredit. Rasio kredit terhadap total dana pihak ketiga yang tinggi menunjukkan bahwa bank yang bersangkutan berada dalam keadaan kurang likuid.

Hasil penelitian ini sejalan dengan hasil penelitian terdahulu yang di lakukan oleh Putra dan Rustariyuni (2015) yang menyatakan bahwa variabel DPK secara simultan mempengaruhi penyaluran kredit.

Dana Pihak Ketiga merupakan hal terpenting dalam hal untuk pembiayaan dan perputaran modal untuk kegiatan operasional dari perusahaan perbankan. Mengingat jasa yang ditawarkan oleh perusahaan perbankan adalah cenderung kepada hal keuangan.

Pengaruh Non Performing Loan Terhadap Penyaluran Kredit

Berdasarkan hasil uji hipotesis secara parsial (uji t) diperoleh hasil bahwa Non Performing Loan berpengaruh signifikan terhadap penyaluran kredit pada perusahaan perbankan yang terdaftar di BEI periode 2013-2016 dengan nilai $(3,425<1.98552)$ atau $t_{\text {hitung }}>\mathrm{t}_{\text {tabel }}(3,425>1.98552$ dan nilai signifikan 0,001 lebih kecil dari 0,05.

Menurut Kasmir (2012:89) adanya resiko kerugian dimana nasabah tidak sanggup lagi untuk membayar semua kewajibannya baik untuk sementara waktu atau selamanya harus segera diantisipasi oleh dunia perbankan. Kalau tidak, sudah dapat dipastikan terjadi kredit macet alias tidak terbayar lagi.

Hasil penelitian ini sejalan dengan hasil penelitian terdahulu yang dilakukan oleh Gredy Normala Sari (2012) yang menyatakan bahwa variabel NPL mempunyai pengaruh signifikan dan serempak mempengaruhi penyaluran kredit. Hal yang sama juga dengan penelitian yang dilakukan oleh Putra dan Rustariyuni (2015) yang menyatakan bahwa variabel NPL secara simultan dan parsial mempengaruhi penyaluran kredit.

Non Performing Loan merupakan problema internal perusahaan dan mempengaruhi minat masyarakat untuk melakukan kredit, dimana nasabah yang membutuhkan dana tetap akan melakukan kredit.

\section{Pengaruh Capital Adequacy Ratio Terhadap} Penyaluran Kredit

Berdasarkan hasil uji hipotesis secara parsial (uji t) diperoleh hasil bahwa Capital Adequacy Ratio tidak berpengaruh dengan nilai (-0,95 $<1.98552)$ atau $t_{\text {hitung }}<t_{\text {tabel }}(-0,95<1.98552$ dan nilai signifikan 0,391 lebih besar dari 0,05.

Kepercayaan masyarakat amat penting bagi bank, karena dengan demikian bank akan dapat menghimpun dana untuk keperluan operasionalnya (Abdullah, 2013).

Hasil penelitian ini tidak sejalan dengan hasil penelitian terdahulu yang dilakukan oleh Syukriah, dkk (2016) yang menyatakan bahwa variabel Capital Adequacy Ratio berpengaruh signifikan terhadap penyaluran kredit.

Capital Adequacy Ratio rasio keuangan yang memberikan indikasi apakah permodalan yang ada telah memadai (adequate) untuk menutup resiko kerugian akan mengurangi modal.

Pengaruh Tingkat Suku Bunga Terhadap Penyaluran Kredit 
Berdasarkan hasil uji hipotesis secara parsial (uji t) diperoleh hasil bahwa Tingkat Suku Bunga tidak berpengaruh dengan nilai $(0,166<1.98552)$ atau ${ }^{t}$ hitung $>$ tabel $(0,166>1.98552$ dan nilai signifikan 0,869 lebih besar dari 0,05.

Hasil penelitian ini tidak sejalan dengan hasil penelitian terdahulu yang dilakukan oleh Nolvia Wijaya (2016) yang menyatakan bahwa tingkat suku bunga secara parsial tidak berpengaruh secara signifikan terhadap penyaluran kredit. Tingkat suku bunga naik maupun turun tidak mempengaruhi penyaluran kredit di suatu bank.

Tingkat suku bunga merupakan pinjaman harus lebih tinggi dari suku bunga simpanan sehingga bank dapat memperoleh keuntungan.

Pengaruh Arus Kas Terhadap Penyaluran Kredit

Berdasarkan hasil uji hipotesis secara parsial (uji t) diperoleh hasil bahwa Arus Kas berpengaruh dengan nilai $(0,802<1.98552)$ atau ${ }^{t}$ hitung $<$ tabel $(0,802<1.98552)$ dan nilai signifikan 0,425 lebih besar dari 0,05 .

Hasil penelitian ini tidak sejalan dengan hasil penelitian terdahulu yang dilakukan oleh Gredy Normala Sari (2012) yang menyatakan bahwa Tingkat Suku Bunga berpengaruh signifikan terhadap penyaluran kredit. Namun, hasil penelitian ini sejalan dengan penelitian yang dilakukan oleh Nolvia Wijaya (2016) yang menyatakan bahwa tingkat suku bunga secara parsial tidak berpengaruh secara signifikan terhadap penyaluran kredit.

\section{KESIMPULAN DAN SARAN}

\section{Kesimpulan}

Berdasarkan hasil pengujian hipotesis yang dilakukan dengan menggunakan spss'17 diperoleh hasil kesimpulan sebagai berikut :

1. Dana pihak ketiga secara parsial tidak berpengaruh terhadap penyaluran kredit.

2. Non Performing Loan secara parsial berpengaruh signifikan terhadap penyaluran kredit.

3. Capital Adequacy Ratio secara parsial tidak berpengaruh terhadap penyaluran kredit.

4. Tingkat Suku Bunga secara parsial tidak berpengaruh terhadap penyaluran kredit.

5. Arus Kas tidak berpengaruh terhadap penyaluran kredit.

6. Dana pihak ketiga, Non Performing Loan, Capital Adequacy Ratio, Tingkat Suku Bunga, dan Arus Kas secara simultan berpengaruh terhadap penyaluran kredit.

\section{Saran}

1. Bagi perusahaan, berdasarkan hasil penelitian tidak terdapat pengaruh Dana Pihak Ketiga, Capital Adequacy Ratio, Tingkat Suku Bunga dengan penyaluran kredit. Sehingga hal yang dapat di lakukan oleh manajer keuangan adalah mencari keputusan lain lain untuk menyalurkan kredit.

2. Bagi Investor, berdasarkan dari hasil penelitian ini investor dapat melihat hasil kinerja keuangan suatu perusahaan perbankan di Bursa Efek Indonesia periode 2013-2016.

3. Bagi Universitas Prima Indonesia, dapat menjadikan ini sebagai bahan referensi kepada peneliti yang akan melanjutkan penelitian dengan judul yang sama

4. Bagi Peneliti selanjutnya, disarankan untuk variabel lain untuk meneliti penyaluran kredit.

\section{DAFTAR PUSTAKA}

Abdullah, T., 2013. Bank dan Lembaga Keuangan. Jakarta: PT. RajaGrafindo Persada.

Dendawijaya, L., 2009. Manajemen Perbankan. Jakarta: Ghalia Press.

Ismail, 2011. Manajemen Perbankan Dari Teori Menuju Aplikasi. Jakarta: Gramedia.

Kasmir, 2012. Manajemen Perbankan. Jakarta: Raja Grafindo Persada.

-------2013. Bank Dan Lembaga Keuangan Lainnya. Jakarta: Rajawali Press.

Sanusi, A., 2012. Metodologi Penelitian Bisnis. Jakarta: Salemba Empat, RajaGrafindo Persada.

Sujarweni \& Wiratna, V., 2015. Akuntansi Manajemen. Yogyakarta: Pustaka Baru Press.

Wardiah, Mia, L. \& Juhaya, P. S., 2013. DasarDasar Perbankan. Bandung: Pustaka Setia.

Hariyani, Iswi, 2010. Restructurisasi Dan Penghapusan Kredit Macet. Jakarta: PT.Elex Media Kamputindo.

Triandara, sigit dan Totok Budisantosio, 2008. Bank Dan Lembaga Keuangan Lain. Jakarta: Salemba Empat. 
Taswan, 2010. Manajemen Perbankan (Konsep, Teknik, dan Aplikasi), Yogyakarta: Edisi Kedua, UPP STIM YKPN.

Wardiah, M.L, 2013. Dasar-dasar Perbankan. Bandung: CV Pustaka Setia.

Hennie van Greuning \& Sonja Brajovic Bratanovic, 2011. Anlyzing Banking Risk, Jakarta: Salemba Empat.

Ghozali, Imam, 2013. Aplikasi Analisis Multivariate dengan Program SPSS, Edisi Ketujuh, Semarang: Badan Penerbit Univesitas Diponegoro.

pujiati, dkk, 2013. pengaruh Non Performing Loan, Capital Adequacy Ratio, Dana Pihak Ketiga Terhadap Penyaluran Kredit pada PT.BCA,Tbk.Bandung:ISSN:1858-2559, Vol.5 oktober 2013.

Igan Bagus Grahadika Putra \& Igap Wirathi, 2013). Pengaruh Loan To Deposit Ratio, BI Rate, Capital
Adequacy Ratio, Non Performing Loan, Terhadap Penyhaluran Kredit UMKM di Bank Umum Provinsi Bali Periode 2004.I-2013.1V, Ejournal:ISSN :2303-0178.

Gedde Oggy Pratama Putra \& Surya Dewi Rurtariyuni, (2014). Pengaruh DPK,BI Rate, Dan NPL Terhadap Penyaluran Kredit Modal Kerja Pada BPR Di Provinsi Bali Tahun 2009-2014, Ejournal:ISSN :2303-0178.

Nolvia Wijaya (2016). Pengaruh Capital Adequacy Ratio, Non Performing Loan, Dan Dana Pihak Ketiga Terhadap Penyaluran kredit pada perusahaan BEI 2014-2016, Medan: Universitas Prima Indonesia.

Greydi Normala Sari, (2012). Faktor-Faktor Yang Mempengaruhi Penyaluran Kredit Bank Umum Di Indonesia Periode 2008.I-2012.2), ISSN:2303-1174 